\title{
Antibodies to laminin in preeclampsia
}

\author{
Jean-Michel Foidart, John Hunt, Charles-Maurice Lapiere, Betty Nusgens, \\ Cécile De Rycker, Michèle Bruwier, René lambotte, Alfred Bernard, \\ and PhilipPe MAHIEU
}

\author{
Departments of Obstetrics and Gynecology, Internal Medicine, and Experimental Dermatology, University of Liege, B 4020 Liege; and the \\ Department of Occupational Medicine, University of Louvain, B 3000 Louvain, Belgium
}

\begin{abstract}
Antibodies to laminin in preeclampsia. Laminin is a large basement membrane glycoprotein localized in the trophoblast, glomerular basement membranc and in the mesangial matrix of human glomeruli. It promotes the attachment of epithelial cells to basement membrane collagen. We have found that 14 sera from 52 patients with severe preeclampsia or eclampsia contain IgG and IgM antibodies which react with placental and kidney basement membranes. These antibodies were specific for laminin and did not react with other basement membrane proteins. They were able to fix complement. They have been demonstrated by radial immunodiffusion, radioimmunoassay and immunotluorescence blocking studies. In primary cultures they were shown to impair the attachment of trophoblast cells to basement membrane collagen. High levels of circulating immune complexes were detected only in sera from preeclamptic patients with circulating antibodies to laminin. The auto-antibodies to laminin could play a major role in the pathogenesis of severe preeclampsia by impairing the attachment of trophoblast cells to placental basement membranes and by fixation to the glomerular basement membranes and mesangial matrix.
\end{abstract}

Preeclampsia is characterized by the onset of hypertension, proteinuria and edema after the 20th week of gestation in previously normotensive women [1]. Despite extensive investigation, the etiology of preeclampsia is unknown. Its incidence is closely linked to increased placental trophoblast mass such as seen in twin pregnancies, diabetes, Rhesus isoimmunization and hydatidiform trophoblastic disease [2].

Histopathologic and immunopathologic studies at autopsy have demonstrated the presence of thrombi in small arteries of patients with preeclampsia [3] as well as focal accumulation of fibrin in glomeruli, liver sinusoids and uteroplacental arterics [4-7]. These findings indicate that local or disseminated activation of the coagulation system may play an important role in the pathogenesis of the disease. A considerable increase in shedding of trophoblast cells from the placenta into the maternal circulation could ultimately be responsible for these documented clotting abnormalitics [8-13].

The mechanisms responsible for the extensive degeneration and shedding of syncytial trophoblast cells during preeclampsia have not been studied. These cells are normally anchored to the trophoblast basement membrane (BM) which contains several

Received for publication June 7, 1985 .

and in revised form Octoher 18,1985

(c) 1986 by the International Society of Nephrology well defined BM glycoproteins, including type IV collagen, entactin, laminin and a heparan sulfate rich proteoglycan [14-16]. Laminin is an ubiquitous BM glycoprotein which promotes the in vitro adhesion of epithelial, endothelial, or muscle cells to BM collagen [17]. Laminin probably also mediates the in vivo attachment of cells to their underlying BM by specific interaction with a cell surface binding protein and BM collagen [18-20]. The effect of anti-laminin antibodies on cell-attachment to BM remains unknown in vivo.

In the present work, we have tested the following hypothesis: some women became immunized against laminin antigens during severe preeclampsia or eclampsia; these anti-laminin antibodies might bind to the trophoblast BM, impairing the anchorage of syncytial cells to their supportive BM, thus allowing their increased shedding into the maternal circulation.

\section{Methods}

Patients

Sera from 27 eclamptic, 45 preeclamptic patients $(20$ mild and 25 severe forms) and 42 normal pregnant women of the same gestational age (30 to 38 wceks) were used. All were primigravid, Mild or severe preeclampsia was defined according to the critcria of the American College of Obstetricians and Gynecologists [1, 21], and of the American Committee on Maternal Welfare [21]. Preeclampsia was classified as mild if one of the following signs or symptoms was found: a) blood pressure of at least $160 \mathrm{mmHg}$ systolic or $110 \mathrm{mmHg}$ diastolic on two occasions at least six hr apart; b) proteinuria of at least $5 \mathrm{~g} / 24 \mathrm{hr}$; c) oliguria (urinary volume of less than $400 \mathrm{mliter} / 24$ hr); d) visual or cerebral disturbances; e) pulmonary edema or cyanosis. The presence of any one or more of these signs marked the preeclampsia as severe. All patients with mild preeclampsia had significant proteinuria $(>0.5 \mathrm{~g} / 24 \mathrm{hr})$. The absence of diabetes, Rhesus isoimmunization, and lupus erythematosus or immune glomerulonephritis was verified by appropriate tests.

\section{Immunofluorescence}

Sera were tested for the presence of anti-BM antibodies by indirect immunofluorescence using human or mouse placenta, kidney, skin or the EHS sarcoma (a murine tumor producing a matrix of BM) as substrates [22, 23]. Non-specific immunoglobulins present in normal placenta were extracted prior to im- 
munofluorescence studies by short term cultures, as described previously [24]. In some studies, the same sections were first incubated with the human sera or with the anti-laminin antibodies $(50 \mu \mathrm{g} / \mathrm{mliter}$ in phosphate buffered saline-PBS) purified by affinity chromatography from these sera [23], and thereafter with rabbit anti-mouse laminin antibodies $(50 \mu \mathrm{g} / \mathrm{mliter})$. After extensive washing with PBS, the distribution of human or rabbit antibodies was revealed by a further incubation of the tissue section with rhodamin-conjugated goat anti-human IgG and with fluorescein-conjugated goat anti-rabbit IgG (Cappel, Pennsylvania, USA). These antibodies were rendered specific for human or rabbit IgG by cross-immunoabsorption [22]. In other studies, tissue sections were pretreated for two hours at $37^{\circ}$ with chondroitinase ABC (50 U/mliter) (Miles Lab., Elkhart, Indiana, USA), testicular hyaluronidase $(40 \mathrm{mg} / \mathrm{mliter}$ in PBS) (type IV, Sigma, St. Louis, Missouri, USA) or bacterial collagenase (50 U/mliter) (Lynbrook form III, Advances Biofactures, USA) in order to unmask antigens before the incubation with the various anti-sera as described above. Immunofluorescence blocking studies were performed by a prior incubation of sera (or affinity purified antibodies) in the presence of type IV or V collagens, laminin, fibronectin or bovine serum albumin at a concentration of $100 \mu \mathrm{g} / \mathrm{mliter}$ for one hour at $37^{\circ}$ and overnight at $4^{\circ}$. The class of antibody bound to the tissue sections was determined by using fluorescein-conjugated goat anti-human IgG or IgM (Cappell Laboratories, Cochranville, Pennsylvania, USA). The ability of these antibodies to activate the complement cascade was tested by an in vitro immunofluorescence complement binding technique. The presence of $\mathrm{C} 3$ deposits was demonstrated after sequential incubations of the tissue sections with the patients' sera, with fresh normal human serum (1:10 dilution in PBS as a source of complement) and with fluorescein-conjugated rabbit antihuman C3 antibody (Cappell) [25].

Double immunodiffusion. Double immunodiffusion according to Ouchterlony was performed at $4^{\circ}$ in $1 \%$ agarose gels as previously described [22].

\section{Antibody purification}

Anti-laminin antibody was purified by affinity chromatography of 20 mliter of "positive" sera on a Sepharose-4B-laminin column [23]. After removal of the unbound material by extensive washing with PBS, bound antibody was eluted with $0.5 \mathrm{M}$ $\mathrm{NaCl}, 0.5 \mathrm{M}$ acetic-acid- $\mathrm{pH}$ 3. Fractions containing protein were adjusted to $\mathrm{pH} 7.4$, dialyzed against PBS, and concentrated to $50 \mu \mathrm{g} / \mathrm{mliter}[22]$.

\section{Elution of immunoglobulins from placenta}

Placental villi from five patients with eclampsia, five with severe preeclampsia and five with normal pregnancy were homogenized using an Ultra-Turrax blender (5 g tissue/20 mliter PBS). Soluble proteins were discarded after repeated extraction of the homogenate with PBS. The insoluble material was then extracted (three times for two hr at $4^{\circ}$ with $0.2 \mathrm{M}$ citrate buffer-pH 2.5) [26]. Pooled supernatants of the extracts were adjusted to neutral $\mathrm{pH}$, dialyzed against PBS and concentrated $100 \times$ by filtration on a UM 10 Amicon filter (Amicon, Lexington, Massachusetts, USA). The protein concentration of placental eluates was measured by the method of Lowry et al [27]. Eluates were also analyzed by immunoelectrophoresis using an antiserum directed against whole human serum (Behring, Hoechst, Belgium).

\section{Immunological Assays}

Antibody to laminin in human serum was detected by precipitation of $\left[{ }^{125} \mathrm{I}\right]$-laminin by a double antibody precipitation method [22], by immunoprecipitation of the immune complexes with polyethyleneglycol (PEG) [28], by a solid phase radioimmunoassay (RIA) using $\left[{ }^{125} I\right]$-protein $A$ [29], and by an automated latex immunoassay [30]. Murine laminin (10 ng) purified from the EHS tumor was labelled with ${ }^{125} \mathrm{I}$ by the method of McConahey and Dixon [31]. Free iodine was separated from protein bound iodine by chromatography on a Biogel P60 column $(60 \times 0.5 \mathrm{~cm})$ followed by dialysis against borate buffer (ionic strength $0.1-\mathrm{pH} 8.3$ containing $0.04 \%$ Tween 20 ) [28]. Binding of the labelled antigen to serial dilutions of human serum or affinity purified antibody was measured by precipitation of the immune complexes with an equal volume of a solution containing $20 \%$ PEG [32, 33], or by double antibody immunoprecipitation [22]. Addition of 0.5 mliter of $20 \%$ PEG solution to 0.5 mliter of normal human serum diluted $40 \times$ with the borate-Tween buffer precipitated less than $5 \%$ of the ${ }^{125}$ I-laminin. In the same conditions, $1 \mu \mathrm{g}$ of rabbit antibody to laminin precipitated 70 to $90 \%$ of total radioactivity. The percentage of ${ }^{125}$ I-laminin precipitated by the $20 \%$ PEG solution in the sera from 42 normal pregnant women (at 1:40 dilution) was $0.3 \pm 3 \%$ (mean $\pm \mathrm{SD})$. This percentage was $0.4 \pm 1 \%$ (mean $\pm \mathrm{SD}$ ) when the second antibody technique was used. A significant laminin binding capacity was considered to occur in serum of patients only when at least $10 \%$ of the ${ }^{125}$ I-laminin was precipitated with PEG or with the second antibody.

Binding of antibody to laminin was also measured by solid phase RIA, using laminin coated plates. Polyvinyl chloride plates (PVC) (Cooke Lab., USA) were coated with laminin by incubation for two hours at $37^{\circ}(100 \mu$ liter/well of $5 \mu \mathrm{g} / \mathrm{mliter}$ laminin in PBS). After washing, residual binding sites were blocked by incubation with $10 \%$ fetal calf serum (FCS) (100 $\mu$ liter/well diluted in PBS-Tween containing 10\% FCS). The wells were then washed three times with PBS-Tween and incubated at $37^{\circ}$ for one hour in the presence of $\left[{ }^{125} \mathrm{I}\right]$-protein $\mathrm{A}$ (50 $\mu$ liter/well of $0.25 \mu \mathrm{g} / \mathrm{mliter}$ ). Unbound material was removed by washing three times with PBS-Tween. Bound radioactivity was measured by counting the cut out wells in a gamma counter (LKB rack gamma II). At least five sera from normal pregnant women were included as controls on each plate. At all dilutions of sera from 30 normal non-pregnant women or 42 normal pregnant women, less than $0.2 \pm 0.1 \%$ of the $\left[{ }^{125} \mathrm{I}\right]-$ protein $A$ was bound to laminin-coated wells, while affinity purified rabbit anti-laminin antibody $(0.6 \mu \mathrm{g} / \mathrm{mliter})$ showed binding of 65 to $70 \%$. Significant binding to laminin was considered to occur only when more than $1 \%$ of total radioactivity bound to the wells.

In inhibition studies, human sera (1:40 dilution in PBS-Tween containing $10 \%$ FCS) were incubated overnight at $4^{\circ}$ in the presence of various antigens (laminin, type IV collagen, heparan-sulfate containing proteoglycan or bovine serum albu$\mathrm{min}$ ) at a concentration of $50 \mu \mathrm{g} / \mathrm{mliter}$ ). After centrifugation for $30 \mathrm{~min}$ at $15,000 \mathrm{rpm}$, supernatants were incubated in triplicate on laminin-coated plates as described above. Percentage inhibition was calculated by comparison of bound radioactivity in 
wells incubated with human sera preincubated without addition of antigen.

Finally, the presence of antibodies to laminin in sera was tested by an automated latex immunoassay [30]. Serially diluted sera (in glycine buffered saline (GBS) $-0.1 \mathrm{M}$ glycine, $0.17 \mathrm{M}$ $\mathrm{NaCl}, 0.0076 \mathrm{M} \mathrm{NaN}_{3}$ adjusted to $\mathrm{pH} 9$ with $\mathrm{NaOH}$ ) were incubated at $42^{\circ}$ for $25 \mathrm{~min}$ with calibrated $(0.8 \mu \mathrm{m}$ in diameter) latex particles on which laminin was adsorbed (12 $\mu \mathrm{g}$ laminin/5 mg latex particle). PEG ( $4 \%$, final concentration) was added to the incubation medium. The agglutination was measured by counting the remaining unagglutinated latex particles with a cell counter as described in details by one of us [30]. Normal human sera at 1:3 dilution agglutinated $5 \%$ of the latex particles. When diluted 24-fold these sera agglutinated less than $1 \%$ of the latex particles. The presence of anti-laminin antibodies was investigated in a large series of samples at this dilution. Human serum diluted 1:24 with GBS was considered to contain antibody to laminin when at least $10 \%$ of the laminin-coated latex particles were agglutinated. An excellent correlation was found between anti-laminin antibody titers determined by the three immunological techniques. Linear regression coefficients between antibody titers determined were respectively: $\left[{ }^{125} \mathrm{I}\right]$-protein A-double antibody precipitation method: $r^{2}=0.88,(P<0.01)$; double antibody precipitation-latex immunoassay : $r^{2}=0.96$, $(P<0.001) ;\left[{ }^{125} \mathrm{I}\right]$-protein A-latex immunoassay : $r^{2}=0.95,(P$ $<0.001)$.

\section{Complement and immune complex assays}

The serum levels of $\mathrm{C} 3$ and $\mathrm{C} 4$ were routinely measured by laser nephelometry (Travenol, Hyland Lab., Costa Mesa, California, USA). Conglutinin test was performed according to Casali et al [34]. Circulating immune complexes were also detected by the classical liquid phase $\left[{ }^{125} \mathrm{I}\right]-\mathrm{Clq}$ binding assay [35].

\section{Adhesion of human trophoblast cells}

Trophoblast cells were isolated by mild trypsin treatment of first trimester placental villi according to Thiede [36]. Cells were applied to a Ficoll-Hypaque gradient (Pharmacia, Uppsala, Sweden), centrifuged at $1200 \mathrm{rpm}$ for $45 \mathrm{~min}$ and pelleted cells discarded. Cells remaining at the interphase were plated in Linbro culture dishes (Flow Lab., USA) with TC 199 medium containing $10 \%$ FCS. Trophoblast identity of these isolated cells was established by the following criteria: a) their morphology by light and electron microscopy; b) their ability to produce placental polypeptide hormones $(4.5 \pm 1 \mu \mathrm{g}$ human placental lactogen, HPL/ $/ 10^{6}$ cells/day and $2 \pm 0.3 \mathrm{IU}$ human chorionic gonadotrophin, $\mathrm{HCG} / 10^{6}$ cells/day); c) their immunostaining after four days in culture of over $90 \%$ of the cells by an anti-HPL antibody using immunofluorescence and/or immunoperoxidase technique. In these experiments, human dermal fibroblasts (sixth passage) were used as control cells.

Adhesion studies were performed according to previously described techniques $[17,37,38]$. Cells were plated on plastic or on type IV collagen ( $1 \mathrm{mliter} /$ well of $10 \mu \mathrm{g} / \mathrm{mliter}$ in $0.1 \mathrm{M}$ acetic acid) prepared either from the EHS tumor [39] or from human placenta [40]. Acetic acid was removed by evaporation for 48 hours under ultraviolet irradiation. For the cell-attachment assay, laminin ( $5 \mu \mathrm{g} / \mathrm{mliter})$ or antibody to laminin $(5 \mu \mathrm{g} / \mathrm{mliter})$ plus cells $\left(2 \times 10^{5}\right)$ were added to the culture medium $(0.9$
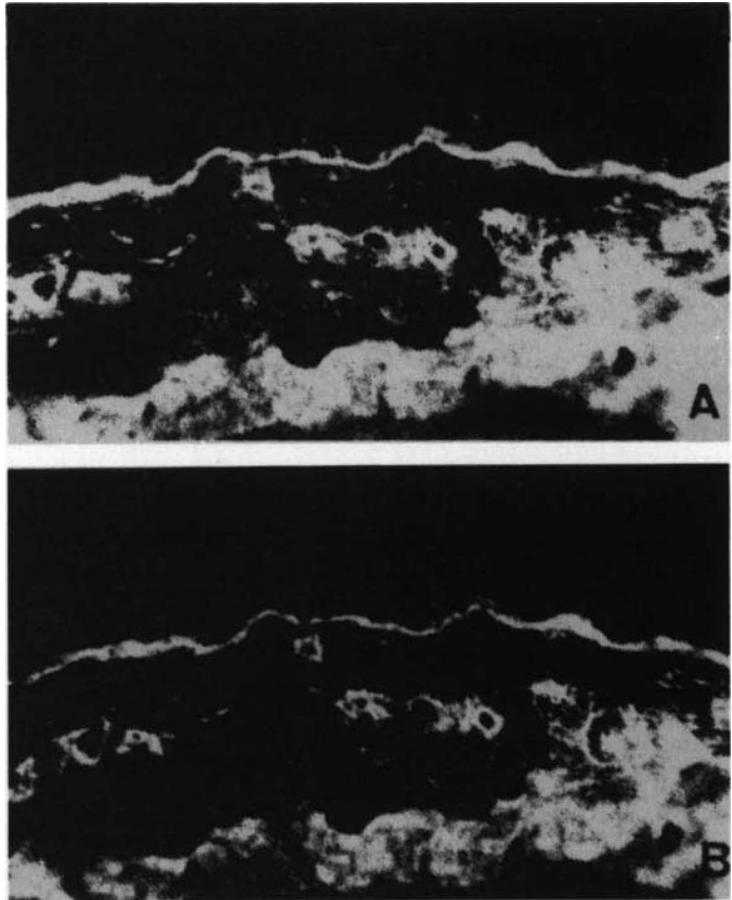

Fig. 1. Normal human skin. Double immunofluorescent localization of human BM using human antibody to laminin purified from serum of eclamptic patients, $\mathbf{A}$, or rabbit antibody purified from antiserum of rabbits immunized against mouse laminin, B $(\times 64)$.

mliter of TC 199 medium containing $10 \%$ FCS). After six hours incubation, unbound cells were removed by washing with fresh culture medium. Attached cells were trypsinized and counted in a Thoma cell and an electronic cell counter (Coulter Counter). At least six assays were performed for each experimental condition.

\section{Results}

\section{Immunofluorescence studies}

No antibody binding to human or animal tissues was detectable by immunofluorescence in the serum from 30 non-pregnant women, 42 normal pregnant women and 20 patients with mild preeclampsia. On the contrary, the sera from five of 25 patients with severe preeclampsia and nine of 27 patients with eclampsia contained antibodies able to bind to human BM in tissues such as placenta, kidney, skin or muscle as demonstrated by immunofluorescence microscopy. Their titers ranged from $1 / 4$ to 1/32. Their tissuc distribution therefore closely resembled that of rabbit antibody against the BM protein laminin [22]. Prior incubation of human sera with laminin completely blocked the binding of these antibodies to the tissue substrates. However, prior incubation with other highly purified connective tissue proteins (including type IV or V collagens, fibronectin, entactin or heparan sulfate proteoglycan) did not strongly modify the substrate binding.

The tissue reactive antibodies could be isolated from the sera of preeclamptic or of eclamptic patients by affinity chromatography on a laminin-Sepharose column. These antibodies bind to BM of human tissues (Fig. 1). The staining pattern was identical to that obtained with the corresponding sera. The pattern of 


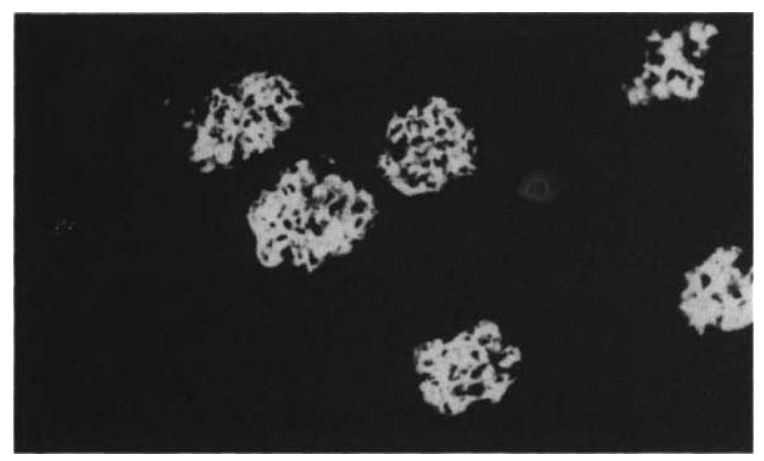

Fig. 2. Distribution in mouse kidney of human antibody to laminin. Hundred micrograms of purified antibody to laminin were injected intravenously in a normal mouse. In vivo bound human immunoglobulin $G$ was detected by immunofluorescence $30 \mathrm{~min}$ later. Immunofluorescent deposits are localized to the glomerular BM ( $\times 64)$.

staining of these affinity-purified anti-laminin human antibodies was then compared to that of rabbit antibodies to laminin by double immunolocalization. Both types of antibodies displayed identical distributions on dermo-epidermal BM, capillary BM and smooth muscle BM (Fig. 1A, B). Both human and rabbit antibodies also bound to the matrix of the EHS sarcoma in an identical pattern (not shown). In kidney, antibodies purified from the sera of preeclamptic or eclamptic women reacted with the mesangial matrix and the glomerular BM as well as with the peritubular capillary BM. Only a faint reaction was detected in Bowman's capsule and tubular BM, whereas rabbit anti-laminin antibodies strongly stained all kidney BM. When injected into mice [41], human antibodies strongly bound to the mesangial matrix and glomerular BM (Fig. 2). These antibodies were shown to be of IgM and IgG classes and able to bind complement. Prior treatment of tissue sections with hyaluronidase, bacterial collagenase or chondroitinase $\mathrm{ABC}$ did not strongly modify the distribution nor staining intensity.

\section{Double immunodiffusion}

The sera from 30 normal non-pregnant, 42 normal pregnant or 20 mild preeclamptic women did not react with laminin in Ouchterlony gels. The sera from two of 27 eclamptic women and three of 25 preeclamptic patients contained antibodies able to precipitate laminin in this test. These same sera contained by immunofluorescence antibodies binding to BM. Affinity purified antibody to laminin from these same sera also precipitated laminin. An identity line was observed between the laminin precipitated by human and rabbit anti-laminin antibodies.

\section{Immunological studies}

Sera from 30 normotensive non-pregnant women, 42 normal primigravid and 20 patients with mild preeclampsia did not contain anti-laminin IgG, detectable by $\left[{ }^{125} \mathrm{I}\right]$-protein $\mathrm{A}$ reacting with antibodies bound to laminin coated wells. On the contrary, anti-laminin IgG was found in serially diluted sera of patients with severe preeclampsia (Fig. 3A). Anti-laminin antibody titers ranged from 80 to 320 . The presence of such antibodies was then evaluated in a large series of patients using a 25-fold dilution of serum in order to further decrease the percentage of non-specific binding. Sera from nine of 27 eclamptic women and five of 25 patients with severe preeclampsia exhibited signifi-
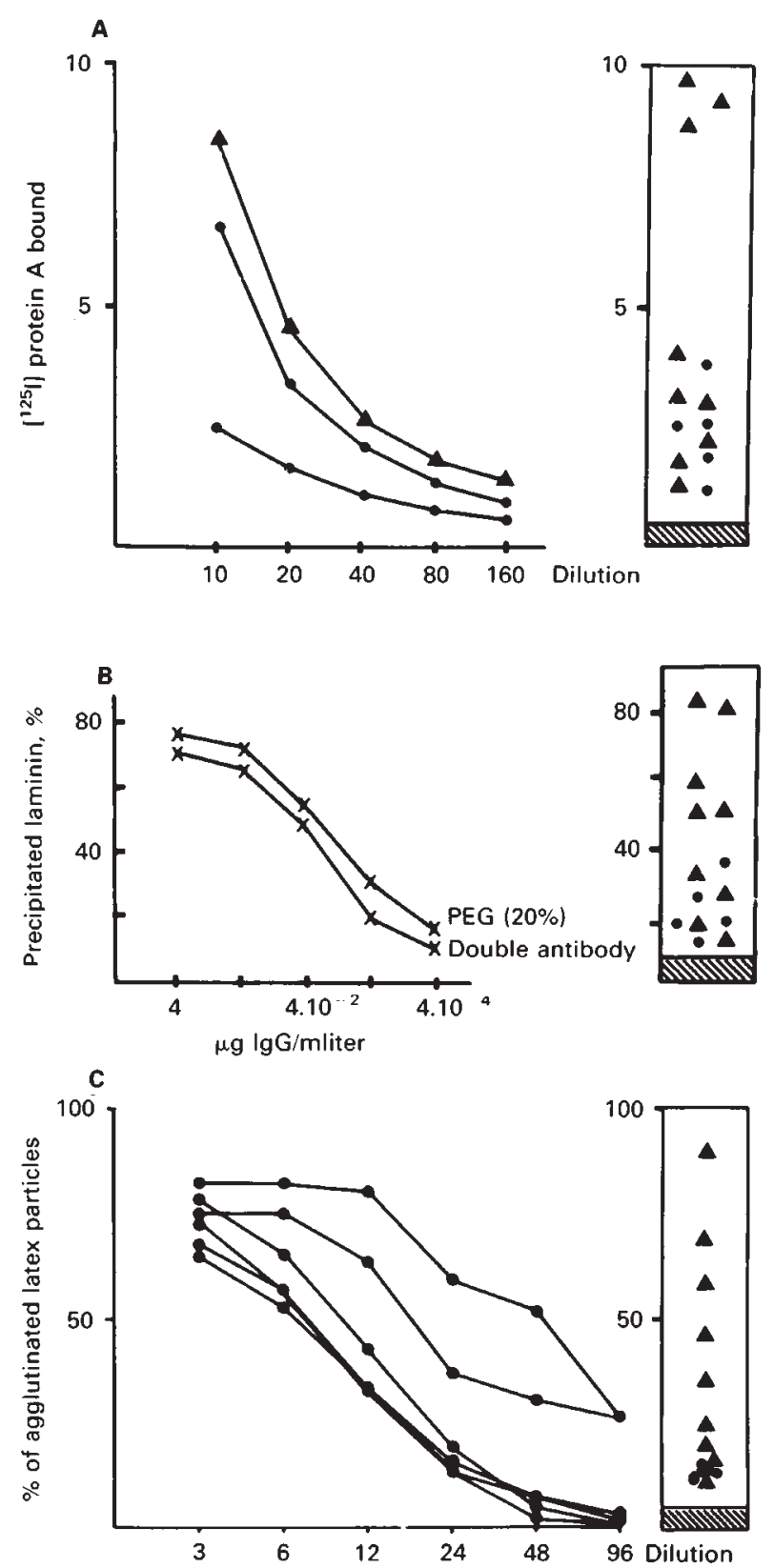

Fig. 3. Detection of anti-laminin antibody by using I $^{I 25} I J$-protein A, A, by radioimmunoassay, $\mathbf{B}$, or by agglutination of latex particles coated with laminin, C. A. Titration curve of two human sera (-) from preeclamptic patients or of human antibody to laminin $(40 \mu \mathrm{g} / \mathrm{mliter})$ purified from sera of eclamptic women $(\boldsymbol{\Delta}-\mathbf{\Delta})$. The right panel indicates the percentage of binding of $\left[{ }^{125} \mathrm{I}\right]$-protein $A$ to laminin-coated wells after incubation in the presence of diluted serum $(1: 25)$ from preeclamptic (O) or eclamptic (A) women. The dashed zone represents the maximal non-specific binding. B. Titration curve of purified rabbit antibody to laminin by radioimmunoassay using either PEG or a double antibody technique in order to precipitate the immune complexes. The right panel shows the percentage of $\left[{ }^{125} \mathrm{I}\right]-$ laminin precipitated by diluted serum $(1: 40)$. C. Titration curve of six sera from preeclamptic patients by agglutination of latex particles coated with laminin. The right panel shows the percentage of agglutinated particles by diluted serum $(1: 24)$.

cant titers of anti-laminin antibody (Fig. 3A). Prior incubation of these sera or of affinity purified human antibodies to laminin 
Table 1. Complement and immune complexes in preeclamptic patients with or without circulating antibody to laminin

\begin{tabular}{|c|c|c|c|c|c|}
\hline \multirow[b]{2}{*}{ Patients } & & \multirow[b]{2}{*}{$N$} & \multicolumn{2}{|c|}{ Complement* } & \multirow{2}{*}{$\begin{array}{c}{\left[{ }^{125} \mathrm{I}\right]-\mathrm{Clq}} \\
\% \text { binding activity }\end{array}$} \\
\hline & & & $\mathrm{C} 3$ & $\mathrm{C} 4$ & \\
\hline $\begin{array}{l}\text { Normal pregnant } \\
\text { women }\end{array}$ & & 42 & $133 \pm 46$ & $23 \pm 4$ & $5.6 \pm 3$ \\
\hline $\begin{array}{l}\text { Preeclamptic-eclamptic } \\
\text { patients }\end{array}$ & $\begin{array}{l}+ \text { antibodies } \\
\text { against laminin } \\
\text { - antibodies }\end{array}$ & 14 & $127 \pm 24$ & $19 \pm 5$ & $37.3 \pm 8$ \\
\hline & against laminin & 60 & $141 \pm 32$ & $26 \pm 7$ & $6.2 \pm 1.6$ \\
\hline
\end{tabular}

Tahle 2. Anti-laminin antibody in placental eluates of eclamptic patients

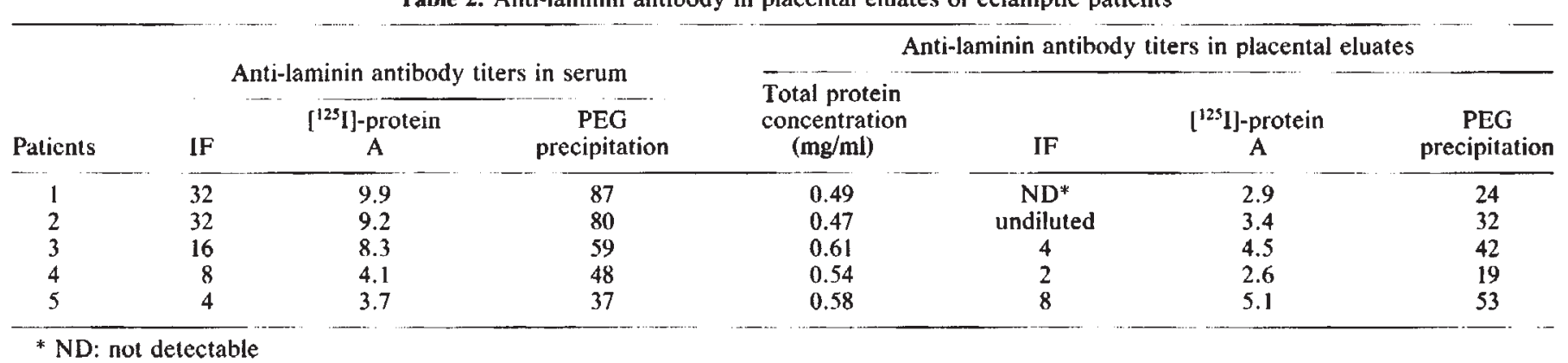

with this antigen completely abolished the binding. Incubation with type IV or $\mathrm{V}$ collagen, fibronectin or bovine albumin did not prevent subsequent binding to laminin coated wells.

Figure $3 \mathrm{~B}$ shows the binding of various concentrations of rabbit anti-laminin antibody to $10 \mathrm{ng}$ of ${ }^{125} \mathrm{I}$-laminin. In the presence of the sera (diluted 40 times) from 20 patients with mild preeclampsia, 42 normal primigravid and 30 normal nonpregnant women, the $20 \%$ PEG solution precipitated less than $10 \%$ of added ${ }^{125}$ I-laminin. On the contrary, sera from five of 25 severe preeclamptic women and nine of 27 eclamptic patients contained significant titers of anti-laminin antibodies (Fig. 3B). Prior incubation of the patient's sera with laminin inhibited antibody binding. In contrast, type IV and $V$ collagens, fibronectin and bovine albumin did not inhibit antibody binding to ${ }^{125}$ I-laminin. Comparable results were obtained using the double antibody immunoprecipitation method.

The presence of antibody to laminin in sera from preeclamptic-eclamptic patients was further confirmed by their ability to agglutinate latex particles coated with laminin (Fig. 3C). Among patients with circulating anti-laminin antibodies, a good correlation was observed between the titcrs defined by the three immunological methods. Higher titers of anti-laminin antibodies were usually found in eclamptic patients as compared with those with preeclampsia (Fig. 3).

\section{Complement and immune complexes}

Serum levels of $\mathrm{C} 3$ and $\mathrm{C} 4$ were unchanged in preeclampticeclamptic women in comparison with those with normal pregnant women of the same gestational age (Table 1). Patients with circulating antibodies to laminin also exhibited normal serum levels of $\mathrm{C} 3$ and $\mathrm{C} 4$. While the conglutinin test was negative in all pregnancies examined, the liquid phase $\left[{ }^{125} \mathrm{I}\right]-\mathrm{Clq}$ binding assay demonstrated the presence of circulating immune com- plexes in the serum from eight of 14 preeclamptic-eclamptic patients showing antibodies to laminin. The six other "positive" patients as well as the other preeclamptic or eclamptic patients and the normal pregnant women exhibited normal values of $\left[{ }^{125} \mathrm{I}\right]-\mathrm{Clq}$ binding activity of their sera (Table 1).

\section{Placental eluates, cord sera}

Placental eluates from five eclamptic women (with circulating antibodies to laminin) contained IgG and IgM as demonstrated by immunoelectrophoresis. Part of these antibodies reacted with laminin by immunofluorescence studies and solid or liquid phase RIA (Table 2). Placental eluates from five normal pregnant women and five preeclamptic patients (whose serum was devoid of anti-laminin antibodies) did not contain detectable amounts of antibody to laminin. Finally, anti-laminin antibody was detected in only two cord sera from newborn babies whose mother's sera exhibited anti-laminin antibody. These infant sera immunoprecipitated $14 \%$ and $18 \%$ of the ${ }^{125}$ I-laminin respectively added to the liquid phase RIA and bound 5 and $10 \%$ of the [ $\left.{ }^{125} \mathrm{I}\right]$-protein $A$ in the solid phase RIA. Serum titers were identical in maternal and fetal sera. Cord serum from the second newborn child also showed significant $\mathrm{Clq}$ binding activity $(15.6 \%)$. Other cord sera from infants of preeclamptic women immunized against laminin $(N=12)$ did not contain antibody to laminin or immune complexes. Such antibodies and immune complexes were also absent from cord sera of 42 normal primigravid and 20 patients with mild preeclampsia.

\section{Influence of human anti-laminin antibodies on trophoblast cell attachment}

Addition of exogenous laminin stimulated attachment in vitro of human trophoblast cells but not fibroblasts to type IV 
Table 3. In vitro effect of human anti-laminin antibodies on human trophoblast cell plating efficiency

\begin{tabular}{|c|c|c|}
\hline \multirow[b]{2}{*}{ Medium } & \multicolumn{2}{|c|}{ Percentage of cells attached to BM collagen } \\
\hline & $\begin{array}{l}\text { Trophoblast } \\
\text { cells }\end{array}$ & Fibroblasts \\
\hline Alone & $49 \pm 5$ & $79 \pm 10$ \\
\hline Containing soluble laminin ( $5 \mu \mathrm{g} / \mathrm{mliter})$ & $71 \pm 7^{*}$ & $85 \pm 9$ \\
\hline Containing human antibody to laminin ( $5 \mu \mathrm{g} / \mathrm{mliter})$ & $35 \pm 8^{* *}$ & $78 \pm 12$ \\
\hline Containing non-specific human IgG ( $5 \mu \mathrm{g} / \mathrm{mliter})$ & $52 \pm 7$ & $75 \pm 7$ \\
\hline Plus laminin $(5 \mu \mathrm{g} / \mathrm{mliter})+$ human antibody to laminin $(5 \mu \mathrm{g} / \mathrm{mliter})$ & $44 \pm 8$ & $83 \pm 8$ \\
\hline
\end{tabular}

* Significantly different from medium alone, $P<0.01$, Student's $t$-test.

${ }^{* *} P<0.05$.

collagen coated dishes (Table 3). Addition of human antibodies to laminin inhibited the adhesion of human trophoblast cells to type IV collagen and also abolished the stimulating effect of this protein on the attachment of trophoblast cells. Normal human IgG did not influence the binding of these cells to type IV collagen. Furthermore, human dermal fibroblast attachment to type IV collagen was not modified by either laminin or antilaminin antibodies (Table 3).

\section{Discussion}

Nine from 27 eclamptic and five from 25 preeclamptic patients sera contained antibodies that reacted with BM. These sera were found to contain moderate titers of antibodies to laminin but not to other connective tissue components. The identification of laminin as the tissue antigen was established by several methods including immunoprecipitation, immunoabsorption, Ouchterlony immunodiffusion, agglutination, binding to laminin coated wells, inhibition immunofluorescent staining, and inhibition RIA in solid and liquid phase.

Reactivity of human anti-laminin antibodies was identical with that of rabbit anti-laminin on BM. However, rabbit antilaminin antibodies reacted uniformly with all BM whereas antibodies from preeclamptic patients showed a distribution limited to most, but not all, BM. We have previously described similar patterns of reactivity of antibodies to laminin in Chagas disease [38]. The heterogeneous rabbit antibodies are probably directed against a variety of antigenic sites in laminin. Antibodies arising in preeclampsia may recognize fewer and different antigenic determinants in laminin. It is also possible that interactions between laminin and other BM components such as entactin, type IV collagen or heparan sulfate proteoglycan might prevent binding of human antibodies to all BM. As might be expected, the titers with human sera were considerably lower than those of rabbit antisera. It is possible that human anti-laminin antibodies bind only to those BM containing a sufficient density of accessible laminin antigen.

It is not clear why patients with severe preeclampsia or eclampsia develop antibodies to laminin. They were not detected in sera from 30 non-pregnant or 42 normal pregnant women. Their absence from mild cases suggests that gestational hypertension is not an auto-immune disease secondary to the onset of anti-laminin antibody. The anti-laminin antibodies in preeclampsia may be the consequence rather than the cause of the disease. Antibodies to trophoblast [42, 43]; to an amniotic fluid glycoprotein [44]; to uncharacterized placental, renal or hepatic antigens [45-47]; or to a placental carbohydrate [48] have been previously described in serum from preeclamptic patients. It is plausible that the development of such antibodies is the consequence of placental lesions and leakage of placental antigens into the maternal circulation.

We have previously described the occurrence of auto-antibodies to laminin in patients with various diseases involving BM such as Chagas disease [38], Goodpasture's syndrome as well as other glomerulonephritides [33, 49]. The presence of antibodies to laminin in serum is thus not restricted to nor specific of preeclampsia-eclampsia.

Failure to observe antibodies to laminin in patients with mild preeclampsia is rather puzzling. Certainly such antibodies ought to be present at an early stage of the disease if they have a pathogenic role. It is possible that the bulk of anti-laminin antibody present in mild preeclampsia is bound to maternal tissues and that this antibody circulates at levels below the assay's detection limit. Diagnosis of mild or severe preeclampsia in this study was based on clinical criteria alone. Renal biopsy confirmation of the absence of underlying kidney disease was not obtained. It is therefore possible that at least part of the patients with mild gestational hypertension had chronic renal disease or conversely that patients classified here as severe preeclampsia-eclampsia have an underlying renal condition [50]. Correlative biopsy data might help in further delineating disease entity and pathogenic significance of antilaminin antibody.

They could, however, play an important pathogenic role and contribute to the severity of lesions in placenta, kidney, liver and uteroplacental arteries. IgM, IgG and C3 deposits in the walls of uteroplacental arteries as well as mesangio-parietal accumulation of IgM and IgG in glomeruli of patients with preeclampsia have been previously documented in severe forms of the disease $[6,7,51-55]$. At least part of this in vivo bound immunoglobulin could include antibodies to laminin since this protein is abundant in those histological structures. Placental eluates from the five eclamptic patients examined contained in vivo bound antibody to laminin. IgG, IgM and C3 deposits have been previously demonstrated by immunofluorescence in villi of normal or preeclamptic women $[24,26]$. The anti-laminin antibodies described here were complement-fixing of $\operatorname{IgM}$ and IgG classes, and as such, could contribute in accelerating the shedding and embolization of trophoblast cells [8-13]. Our demonstration that anti-laminin antibody specifically inhibited in vitro the binding of trophoblast cells to BM collagen further supports the hypothesis that these antibodies could play an important role in the in vivo detachment and embolization of 
these cells during preeclampsia. We have previously shown that purified rabbit antibody to laminin administrated intravenously to pregnant mice induced proteinuria as well as a high incidence of abortion, retroplacental hematoma and fetal death [41, 56]. Binding of antibodics against laminin to placental BM could also partly explain the increased degeneration of the syncytial trophoblast [57] and the decreased laminin content of preeclamptic villi [58]. It is thus tempting to speculate that antibodies to laminin demonstrated here may play a significant role in severe preeclampsia.

If antibodies to laminin were pathogenic in causing the disease, or aggravating renal and placental lesions, one might wonder why preeclampsia is usually a disease of the first pregnancy only. Goodpasture syndrome, another renal disease, closely related to the presence of circulating anti-BM antibody [59], however, does not usually recur after renal transplantation provided that surgery be performed after disappearance of the circulating anti-BM antibody [60]. One might thus speculate that the anti-laminin antibodies present in preeclampsia could, like in the Goodpasture syndrome, play an important pathogenic role but not recur in subsequent pregnancies after disappearance from serum.

The occurrence of circulating immune complexes during preeclampsia is controversial because different methods have yielded contradictory results. Masson, Delire and Cambiaso [61] described high levels of immune complexes in blood of normal pregnant women. Thomson et al [62], Stirrat, Redman and Levinsky [6.3] and Vazquez-Escobosa, Perez-Medina, and Gomez-Estrada $|64|$ could only identify such complexes in serum of preeclamptic women. Knox et al [65] did not demonstrate any circulating immune complexes in sera of normal or preeclamptic pregnant women. The presence of such complexes only in paticnts sera containing antibodies against laminin suggests that some of these immune complexes could contain laminin anti-laminin antibodies. Their pathogenic significance in preeclampsia remains unknown.

Altogether this study indicates that patients with severe preeclampsia or eclampsia may have circulating and in vivo bound antibodies to laminin. Such antibodies may play an important pathogenic role. Further clinical studies are required to evaluate the possible prognostic significance and the clinical importance of the antibodies demonstrated here.

Reprint requests to Dr. J. M. Foidart, Department of Obstetrics and Gynecology, University of Liege, 81, bd de la Constitution, B-4020 Liege, Belgium

\section{References}

1. Hugnes EC: Obstetric Gynecologic Terminology. Philadelphia, Davis, 1972, p. 423

2. CAUCH MN: Preeclampsia and other pregnancy associaled conditions, in Obstetric and Perinatal Immunology, edited by ARNoLD E, London, 1981, p. 64

3. Mckay D, Merrili. SJ, Weiner aE, Hertic A't, Reid DE: The pathologic anatomy of cclampsia, bilateral renal cortical necrosis, pituitary necrosis, and other acute fatal complications of pregnancy and its possible relationship to the generalized Schwartzman phenomenon. Am J Obstel Gynecol 66:507-539, 1953

4. VAssal.i. P, Morris RH, MCCluskey R'T: The pathogenic role of fibrin deposition in the glomerular lesions of toxemia of pregnancy. $J$ Exp Med 118:467-477, 1963

5. Arias F, Mancilla-Jimenez R: Hepatic fibrinogen deposits in preeclampsia. N Engl J Mcd 295:578-582, 1976

6. Nochy D, Birembaut P, Hinglais N, Friund M, Idatte JM, Jacquot C, Chartier M, BARIETY J: Renal lesions in the hypertensive syndromes of pregnancy. Immunomorphological and ultrastructural studies in $1 / 4$ cases. Clin Nephrol 13:155-162, 1980

7. KitZMILLER JL, WATt N, DRISCOLL. SG: Decidual arteriopathy in hypertension and diabetes in pregnancy: immunofluorescent studies. Am J Obstet Gynecol 141:773-779, 1981

8. Schmort. G: Pathologisch-Anatomische Untersuchungen über Puerperal Eklampsie. Leipzig, Vogel, 1893

9. SCHMORL G: Uber das Schicksal Embolisch Verschleppter Placentarzellen. Zentralb f Gynäkol 29:129-137, 1905

10. Dougias GW, Thomas L, Carr M, Cullen NM, Morris R: Trophoblast in the circulating blood during pregnancy. Am J Obstet Gynecol 78:960-973, 1959

11. Thomas L, Douglas GW, Carr MC: The continual migration of syncytial trophoblasts from the fetal placenta into the maternal circulation. J Exp Med 111:140-148, 1959

12. ATtwood HD, PARK WW: Embolism to the lungs by trophoblast. J Obstet Gynaceol Bril Cw'th 68:611-617, 1961

13. JaAmeri KEU, Kolvuniemi AP, CARPEN EO: Occurrence of trophoblasts in the blood of toxaemic patients. Gynaecologia 160:315-320, 1965

14. Foldart JM, Tryggvason K, Gehron Robey P, Liotta L, MARTIN GR: Biosynthesis of type IV and type V (A-B) collagens by human placenta. Collagen Rel Res 1:137-150, 1981

15. Foidart JM, Timpl R, Furthmayr H, Martin GR: Laminin, a glycoprotein from basement membranes, in Immunochemistry of the Exiracellular Matrix, edited by FurThmaYr H, New York, CRC Press, 1982, p. 125

16. FOIDART JM, YAAR M: Type IV collagen, laminin and fibronectin at the dermo-epidermal junction, in Epidermal Keratinocyte Differentiation and Fibrillogenesis, in Frontiers of Matrix Biology, edited by Prunieras M, Robert L, Basel, S. Karger, 1981, vol. 9, p. 175

17. Terranova VP, Rohrbach DH, Martin GR: Role of laminin in the attachment of PAM 212 (epithelial) cells to basement membrane collagen. Cell 22:719-726, 1980

18. KLlinman HK, KLEBE RJ, MaRTIN GR: Role of collagenous matrices in the adhesion and growth of cells. J Cell Biol 88:473-485, 1981

19. LESOT H, KUHL U, VON DER MARK K: Isolation of a laminin-binding protein from muscle cell membranes. EMO J 2:861-865, 1983

20. RaO NC, BARSKY SH, TERRANOVA VP, LIOTTA LA: Isolation of a tumor cell laminin receptor. Biochem Biophys Res Commun 111:804-808, 1983

21. Chesley LC: Hyperlensive Disorders in Pregnancy, New York, Appleton-Century-Crofts, 1978

22. Foidart JM, Bere EW, Yaar M, Rennard Si, Gullino M, MARTIN GR, KATZ SI: Distribution and immunoelectron microscopic localization of laminin, a non collagenous basement membrane glycoprotein. Lab Invest 42:336-342

23. FOIDART JM, REDDI AH: Immunofluorescent localization of type IV collagen and laminin during endochondral bone differentiation and regulation by pituitary growth hormone. Dev Biol 75:130-136, 1980

24. Foidart JM, Yaar M, Hali, R, Gaspard U, Katz SI: Immunopathological and clinical studies in Herpes Gestationis. $\mathrm{Br} J$ Obstet Gynaccol 88:153-159, 1981

25. Jordon RE, Sams WM, Beutner EH: Complement immunofluorescent staining in bullous pemphigoid. $J$ Lab Clin Med. $74: 548-556,1969$

26. MCCormick JN, Faulk WP, Fox H, Fudenrerg HH: Immunohistological and elution studies of the human placenta. $J$ Exp Med, 133:1-18, 1971

27. Lowky OH, Rosebrough NJ, Farr AL, Randal., RJ: Protein measurement with the Folin Phenol reagent. $J$ Biol Chem $193: 265-273,1951$

28. Mahieu P', Lambert PH, Maghuin-Rogister GR: Primary structure of a small glycopeptide isolated from human glomerular basement membranc and carrying a major antigenic site. Eur $J$ Biochem 40:599-606, 1973

29. LANGone JJ, BoYlL: MDP, Borsos T: A solid-phase immunoassay for human immunoglobulin $\mathrm{E}$-use of ${ }^{125} \mathrm{I}$ labeled protein $\mathrm{A}$ as the 
tracer. Ann Biochem 93:207-215, 1979

30. Bernard AM, Lauwerys RR: Continuous-flow system for automation of latex immunoassay by particle counting. Clin Chem 29:1007-1011, 1983

31. McConahey PJ, Dixon FJ: A method of trace iodination of proteins for immunological studies. Int Arch Allergy 29:185-189, 1966

32. Mahieu P, Lambert PH, Miescher PA: Detection of antiglomerular basement membrane antibodies by a radioimmunological method. J Clin Invest 54:128-137, 1974

33. Foldart JB, Pirard YS, Foldart JM, Dubois CH, Mahieu P: Evidence for a polyclonal stimulation in Goodpasture's syndrome, in Plasma Exchange Plasmapheresis-Plasma Separation, edited by SieberTH H, Stuttgart, London, F. K. Schattauer Verlag, 1981, p. 3

34. Casali P, Bossus A, Carpentier N, Lambert PH: Solid-phase enzyme immunoassay or radioimmunoassay for the detection of immune complexes based on their recognition by conglutinin: conglutinin binding test. Clin Exp Immunol 29:342-354, 1977

35. Creighton WD, Lambert PH, Miescher PA: Detection of antibodies and soluble antigen-antibody complexes by precipitation with polyethylene-glycol. $J$ Immunol 111:1219-1227, 1973

36. Thiede HA: Studies of the human trophoblast in tissue culture. Am J Obstet Gynecol 79:636-647, 1960

37. Salomon Da, Liotta LA, Rennard Si, Foidart JM, TerRANOVA VP, YAAR M: Stimulation by retinoic acid of synthesis and turnover of basement membrane in mouse embryonal carcinoma-derived endoderm cells. Collagen Rel Res 2:93-110, 1982

38. Szarfman a, Terranova VP, Rennard Si, Foidart JM, de Fatima Lima M, Scheinman JI, Martin GR: Antibodies to laminin in Chagas' disease. J Exp Med 155:1161-1171, 1982

39. Timpl R, Martin GR, Bruckner P, Wick G, Wiedemann H: Nature of the collagenous protein in a tumor basement membrane. Eur J Biochem 84:43-52, 1978

40. KRESINA TF, MILlER EJ: Isolation and characterization of basement membrane collagen from human placental tissue. Evidence for the presence of two genetically distinct collagen chains. Biochemistry 18:3089-3097, 1979

41. Foidart JM, YaAr M, Figueroa A, Wilk A, Brown KS, LIOTTA LA: Abortion in mice induced by intravenous injections of antibodies to type IV collagen or laminin. Am J Pathol 110:346-357, 1983

42. Hulka JF, Hsu KC, Beiser SM: Antibodies to trophoblasts during the postpartum period. Nature 191:510-513, 1961

43. Hulka JF, Brinton V: Antibody to trophoblast during early postpartum period in toxemic pregnancies. Am J Obstet Gynecol 86:130-134, 1963

44. Lambotte R: Composition antigénique du liquide amniotique. Rôle éventuel des phénomènes d'isoimmunisation dans la pathologie de la grossesse, in Collection Médico-Monographies d'Agrégés, edited by ARscia, Bruxelles, 1969, p. 1

45. WILKEN H: Über den nachweis von gewebs-antikörpern gegen plazenta, leber und niere in der schwangerschaft. $Z$ Geburtsh Gynäkol 161:113-131, 1963

46. Gaugas JM, Jones E, Curzen P: Spontaneous lymphocyte transformation in pregnancies complicated by pre-eclampsia. Am J Obstet Gynecal 121:542-544, 1975

47. VARDI J, HALBRECHT I: Toxemia of pregnancy. I-Antigens associated with toxemia of pregnancy in placental connective tissue. $A m$
J Obstet Gynecol 118:552-558, 1974

48. KAKU M: Placental polysaccharide and the aetiology of the toxaemia of pregnancy. J Obstet Gynecol Brit Cwlth 60:148-156, 1953

49. Mahieu P, Foidart JB, Foidart JM, Dubois CH, Sieberth HG: Plasma exchange and anti-basement membrane antibody titers in Goodpasture's syndrome. Clin Nephrol 10:21-29, 1981

50. LindHeimer MD, KATZ SI: Kidney function and disease in pregnancy, in Hypertensive Complications of Pregnancy, edited by LEA and Febiger, Philadelphia, 1977, p. 188

51. KitZmiller JL, BeniRschKe K: Immunofluorescent study of placental bed vessels in pre-eclampsia. Am J Obstet Gynecol $115: 248-251,1973$

52. Petrucco om, Thomson NM, Lawrence JR, Weldon MW: Immunofluorescent studies in renal biopsies in pre-eclampsia. $\mathrm{Br}$ Med J 1:473-476, 1974

53. Tribe CR, Smart GE, Davies DR, Mackenzie JC: A renal biopsy study in toxaemia of pregnancy. J Clin Pathol 32:681-692, 1979

54. HUSTIN J, FoIDART JM, LAMBotTE R: Maternal vascular lesions in pre-eclampsia and intra-uterine growth retardation. Light microscopy and immunofluorescence. Placenta 4:489-498, 1983

55. Foidart JM, Nochy D, Nusgens B, Foidart JB, Mahieu PR, LAPIERE CM, LAMBOTTE R, BARIETY J: Accumulation of several basement membrane proteins in glomeruli of patients with preeclampsia and other hypertensive syndromes of pregnancy. Possible role or renal prostaglandins and fibronectin. Lab Invest 49:250-259, 1983

56. YaAr M, Foidart JM, Brown KS, Rennard SI, Martin GR, LIOTTA L: The Goodpasture-like syndrome in mice induced by intravenous injections of anti-type IV collagen and anti-laminin antibody. Am J Pathol 107:79-91, 1982

57. McLennan AH, Sharpe F, Shaw-Dunn J: The ultrastructure of human trophoblast in spontaneous and induced hypoxia using a system of organ culture: a comparison with ultrastructural changes in pre-eclampsia and placental insufficiency. J Obstet Gynecol Brit Cwlth 79:113-121, 1972

58. Risteli J, Foidart JM, Risteli L, Boniver J, Goffinet G: The basement membrane proteins, laminin and type IV collagen in isolated villi in pre-eclampsia. Placenta 5:541-550, 1984

59. Wieslander J, BYGREN P, HeINEGARD D: Isolation of the specific glomerular basement membrane antigen involved in Goodpasture syndrome. P.N.A.S. 81:1544-1548, 1984

60. Hamburger J, Crosnier J, Grünfeld JP: Néphrologie. Flammarion et Co., Orleans, 1979

61. Masson PL, Delire M, Cambiaso CL: Circulating immune complexes in normal human pregnancy. Nature 266:542-543, 1977

62. Thomson NC, Stevenson RD, Behan WM, Sloan DP, Horne $\mathrm{C}$ : Immunological studies in preeclamptic toxaemia. $\mathrm{Br} \mathrm{Med} J$ 1:1307-1309, 1976

63. Stirrat GM, Redman CWG, Levinsky RJ: Circulating immune complexes in pre-eclampsia. $\mathrm{Br}$ Med $J 1: 1450-1451,1978$

64. Vazouez-Escobosa C, Perez-Medina R, Gomez-Estrada H: Circulating immune complexes in hypertensive disease of pregnancy. Obstet Gynecol 62:45-48, 1983

65. Knox GE, Stagno S, Volanakis JE, Huddleston JF: A search for antigen-antibody complexes in pre-eclampsia: further evidence against immunologic pathogenesis. Am J Obstet Gynecol 132:87-89, 1978 